Marquette University

e-Publications@Marquette

College of Education Faculty Research and

Publications

Education, College of

$1-1-2011$

\title{
Content Analysis of Acculturation Research in Counseling and Counseling Psychology: A 22-Year Review
}

Eunju Yoon

Loyola University Chicago

Kimberly Langrehr

Loyola University Chicago

Lee $\mathrm{Za} \mathrm{Ong}$

Marquette University, leeza.ong@marquette.edu

Accepted version. Journal of Counseling Psychology, Vol. 58, No. 1 (January 2011): 83-96. DOI.C

2011 American Psychological Association. Used with permission.

This article may not exactly replicate the final version published in the APA journal. It is not the copy of record. 


\title{
Content Analysis of Acculturation Research in Counseling and Counseling Psychology: A 22-Year Review
}

\author{
Eunju Yoon \\ Counseling Psychology Program, Loyola University Chicago \\ Chicago, IL \\ Kimberly Langrehr \\ Counseling Psychology Program, Loyola University Chicago \\ Chicago, IL \\ Lee Za Ong \\ Department of Counselor Education and Counseling Psychology \\ Marquette University \\ Milwaukee, WI
}

\begin{abstract}
The authors conducted a 22-year (1988-2009) content analysis of quantitative empirical research that included acculturation and/or enculturation as a study variable(s). A total of 138 studies in 134 articles were systematically evaluated from 5 major American Psychological Association and American Counseling Association journals in counseling and counseling psychology, including Journal of Counseling Psychology, The Counseling Psychologist, Journal of Counseling and Development, Journal of


Multicultural Counseling and Development, and Cultural Diversity and Ethnic Minority Psychology. To guide the analysis, the authors conceptualized acculturation/enculturation as a "bilinear" (i.e., developing cultural orientations to both majority and ethnic cultures) and "multidimensional" (i.e., across multiple areas such as behaviors, values, identity, and knowledge) cultural socialization process that occurs in interaction with "social contexts" (e.g., home, school, work, West Coast, Midwest). Findings include the patterns and trends of acculturation/enculturation research in (a) conceptualization and use of acculturation/enculturation variable(s), (b) research designs (e.g., sample characteristics, instruments, data collection, and analysis methods), (c) content areas, and (d) changes in total publications and trends over time. Additionally, meta-analyses were conducted on the relationship of acculturation/enculturation and a few key variables of mental health, adjustment, and well-being. Major findings and directions for future research are discussed.

Since the 1980s, interests in acculturation research have increased in the counseling and counseling psychology field, reflecting the emergence of multicultural movement in the field and the influx of immigrants to the United States after the enactment of the Immigration Reform Act in 1965. Starting in the 1980s, Berry and his colleagues developed a landmark acculturation theory that many counseling and counseling psychology researchers have used as a framework to conceptualize and study acculturation experiences (see Berry, 1980, 1994, 1995, 1997; Berry \& Sam, 1996). For example, the terminology used in Berry's typology of acculturation strategies (i.e., assimilation, separation, integration, and marginalization) has become a common language in the acculturation literature (for a critical review of the typology, see Rudmin, 2003; Schwartz, Unger, Zamboanga, \& Szapocznik, 2010). Together with Berry's acculturation theory, LaFromboise, Coleman, and Gerton's (1993) classic article on the psychological impact of biculturalism highlighted the importance of developing cultural competence in ethnic minority cultures as well as in the mainstream culture. As predicted in a 1988 survey of multicultural counseling researchers (Heath, Neimeyer, \& Pedersen, 1988), acculturation has emerged as a leading variable in counseling and counseling psychology research with the advancement of acculturation theories and the subsequent development of acculturation measures since the publication of the Acculturation Rating Scale for Mexican Americans (ARSMA; Cuéllar, Harris, \& Jasso, 1980). 
Despite the proliferation of acculturation research over the course of two decades, as recently as 2010, no empirical research has evaluated how acculturation research has been conducted in the field of counseling and counseling psychology. Given the importance of acculturation/enculturation variable in understanding within-group variability of ethnic minority clients as well as its association with other psychological, behavioral, and health variables (Ponterotto, Baluch, \& Carielli, 1998), it is important to review how acculturation research has been conducted. A review of past research gives a historical perspective as to how the field has grown and progressed (Buboltz, Miller, \& Williams, 1999). Additionally, a review can help appraise the strengths and weaknesses within the field to guide directions for future research. Thus, in the present study we attempted to evaluate how acculturation research has evolved in the field of counseling and counseling psychology. In this article, we provide an overview of how acculturation/enculturation is conceptualized in the current literature. We then present the results of the content analysis of quantitative empirical studies in counseling and counseling psychology that used acculturation and/or enculturation as a study variable(s).

\section{Acculturation/Enculturation}

Redfield, Linton, and Herskovits's (1936) classic definition of acculturation states, "Acculturation comprehends those phenomena which result when groups of individuals sharing different cultures come into continuous first-hand contact, with subsequent changes in the original culture patterns of either or both groups" (p. 149). This definition allows for bidirectional impacts - two cultures of contact giving and receiving impact to and from each other. In practice, however, the magnitude of impact on one culture may not be equivalent to the impact on the other culture. For example, a minority group (e.g., immigrant group) is more likely to acculturate to a dominant group (e.g., host group) for survival and success in the mainstream cultural context, as opposed to a dominant group acculturating to a minority culture (Berry, 1997). In addition, although acculturation can proceed either at a collective/group level (e.g., a U.S. school cafeteria adopting Mexican food on the menu) or at an individual level (i.e., psychological acculturation; Graves, 1967), 
counseling and counseling psychology research has predominantly focused on psychological acculturation at an individual level.

Acculturation can be broadly defined as "cultural adaptation that occurs as a result of contact between multiple cultures" (Miller, 2007, p. 118). Although acculturation can occur in any intercultural contact (Schwartz et al., 2010), from the perspectives of ethnic minorities and immigrants, acculturation is most often considered as cultural socialization to the majority culture, whereas enculturation is the retention of (e.g., for the first generation immigrants) or cultural socialization to (e.g., for the second or third generation immigrants) one's culture of origin (Berry, 1994; Kim \& Abreu, 2001; Kim, Atkinson, \& Umemoto, 2001). Here, cultural socialization is explicit and implicit transmission of cultural values, beliefs, worldviews, behaviors, and customs (see Arnett, 1995); furthermore, for ethnic minorities, cultural socialization generally proceeds in two broad contexts: majority culture and ethnic minority culture.

Acculturation/enculturation can further be viewed as a "bilinear," "multidimensional" cultural socialization process that occurs in interaction with "social contexts" (Kim \& Abreu, 2001; Miller, 2007; Schwartz et al., 2010; Zea, Asner-Self, Birman, \& Buki, 2003). Different researchers have used different terms to describe this process. For example, to describe whether acculturation proceeds on a single continuum (i.e., the more one is acculturated, the less one is enculturated) or whether acculturation and enculturation proceed relatively independently from each other, some researchers used the terms of unilinear versus bilinear (Kim \& Abreu, 2001; Zea et al., 2003), and others used the terms of unidimensional versus bidimensional (Abe-Kim, Okazaki, \& Goto, 2001; Ryder, Alden, \& Paulhus, 2000; Tsai, Ying, \& Lee, 2000). According to Miller's (2007) suggestion to standardize the terminology to reduce miscommunication and increase conceptual clarity in the acculturation field, we used "unilinear versus bilinear" to describe a dependent versus independent relationship between acculturation and enculturation. Conversely, "multidimensional" refers to the multiplicity of areas in which acculturation occurs (e.g., across behaviors, values, knowledge, and identity).

Journal of Counseling Psychology, Vol. 58, No. 1 (January 2011): pg. 83-96. DOI. This article is @ American Psychological Association and permission has been granted for this version to appear in e-Publications@Marquette. American Psychological Association does not grant permission for this article to be further copied/distributed or hosted elsewhere without the express permission from American Psychological Association. 
The previously introduced definitions of acculturation and enculturation are based on "bilinear" conceptualization. Contrary to the unilinear model that interprets acculturation as a movement on a single continuum (i.e., acculturation occurs in expense of enculturation), the bilinear model posits that individuals can develop cultural orientations to both the majority (dominant, mainstream, host) culture and the culture of origin (ethnic, indigenous, home) and that these two orientations are relatively independent of each other (Cuéllar, Arnold, \& Maldonado, 1995; Kim \& Abreu, 2001; Zea et al., 2003). Accordingly, the acculturation and enculturation processes are represented on two orthogonal continua as opposed to a single continuum (Berry, 1994; Kim \& Abreu, 2001; Kim et al., 2001). Moreover, if multiple cultural contexts are present, it is possible to develop multilinear cultural orientations by acculturating to other ethnic minority cultures in addition to the majority culture (e.g., a Chinese American residing in an African American community of the United States; Lee, Yoon, \& Liu-Tom, 2006).

With the shift in acculturation theory, research, and measurement from the unilinear to the bilinear paradigm, a few studies examined the direct relationship between two cultural orientations. Tsai et al. (2000) found nonsignificant to moderate ( $r=$ -.33) relationships between "being Chinese" and "being American"the relationships varying depending on Chinese Americans' age of immigration and their generational status. Similarly, Lee et al. (2006) found that acculturation dimensions (e.g., social interaction, languages), generational status (e.g., immigrant vs. U.S. born), and contexts (e.g., West Coast vs. Southwest) determined the small to moderate correlations ( $r$ range $=-.12$ to -.41 ) between Asian and mainstream cultural orientations. These nonsignificant to moderate associations suggest that acculturation and enculturation are "bilinear" processes that are related to each other to varying degrees rather than being either opposite ends of a continuum (i.e., unilinear) or two completely orthogonal, independent constructs. The relationship between two cultural orientations may depend on a host of variables, such as generational status, age of immigration, acculturation dimensions, and contexts (e.g., ethnic density, diversity policy of the host society). In further support of the bilinear model, acculturation and enculturation showed patterns of noninverse correlations with other variables (i.e., personality, self-identity, and psychosocial 
adjustment), indicating relative independence of the two constructs (Ryder et al., 2000).

In addition to the discussion on linearity, researchers have proposed that acculturation/enculturation proceed across multiple dimensions. According to Szapocznik, Scopetta, Kurtines, and Aranalde (cited in Kim \& Abreu, 2001), acculturation occurs in two dimensionsbehaviors (e.g., language use, participation in cultural activities) and values (e.g., relational style, person-nature relationships, beliefs about human nature, time orientation)-whereas Berry (cited in Kim \& Abreu, 2001) specified six dimensions of acculturation: language, cognitive styles, personality, identity, attitudes, and acculturative stress. More recently, Cuéllar et al. (1995) named three levels of acculturation functioning-behavioral (e.g., language, food), affective (e.g., emotions, identity), and cognitive (e.g., beliefs, values)whereas Kim and Abreu (2001) identified four basic dimensions of behavior, values, knowledge, and cultural identity. Similarly, Schwartz et al. (2010) identified three dimensions of acculturation: practices, values, and identification. Although the scope of each dimension varies, acculturation dimensions have been found to be more or less related to one another. For instance, Yoon's (2006) exploratory factor analysis of the Abbreviated Multidimensional Acculturation Scale (Zea et al., 2003) in a community sample of Korean immigrants revealed that the items representing the Korean language and Korean cultural competency subscales loaded on separate factors; however, the items for the subscales of the English language and U.S. cultural competency loaded on the same factor, indicating a close link between English language skills and U.S. cultural competency.

In addition, acculturation has been found to proceed at various rates across dimensions. Szapocznik and his colleagues proposed that, to survive in a new culture, individuals should learn the necessary behaviors before acquiring a new value system (Szapocznik, \& Kurtines, 1980; Szapocznik, Kurtines, \& Fernandez, 1980). In support, a study on familialism revealed that Latino participants were less likely to acculturate in attitudinal familialism (e.g., feelings of loyalty, solidarity, and reciprocity) than in behavioral familialism (e.g., visiting patterns; Sabogal, Marin, Otero-Sabogal, VanOss Marin, \& PerezStable, 1987). Similarly, Kim, Atkinson, and Yang (1999) found that behavioral acculturation occurred faster than value acculturation

Journal of Counseling Psychology, Vol. 58, No. 1 (January 2011): pg. 83-96. DOI. This article is @ American Psychological Association and permission has been granted for this version to appear in e-Publications@Marquette. American Psychological Association does not grant permission for this article to be further copied/distributed or hosted elsewhere without the express permission from American Psychological Association. 
among Asian American college students. Even within the behavioral dimension, acquisition of the English language was found to precede mainstream social interactions (Lee et al., 2006). J. Hong and Min (1999) also discovered high language assimilation versus low social assimilation among second generation Korean Americans. Phinney's (2003) research with ethnic minorities further revealed that ethnic identity declined from the first to the second generation but that this decline leveled off or noticeably slowed down in later generations, whereas cultural knowledge, practice, or behaviors typically indicated a substantial and continuing decline across generations. Phinney attributed this discrepancy in acculturation patterns of ethnic identity and other dimensions to racism and discrimination. Regardless of generational status, it is likely that non-European ethnic groups should preserve ethnic identity to have a sense of group solidarity in the face of discrimination (Phinney, 2003). As demonstrated by the aforementioned studies, the varying rates and patterns of acculturation/enculturation across areas warrant research attention to specific dimensions as well as overall levels of acculturation/enculturation.

Given that acculturation/enculturation does not occur in a vacuum, but through interactions between an individual and his/her environment, acculturation/enculturation experiences may also depend on "social contexts" (Kim \& Abreu, 2001; Kim et al., 2001; Lee et al., 2006). Berry called attention to contextual factors of economic, social, and political variables (e.g., social support, prejudice and discrimination, diversity policy) in both society of origin and society of settlement (Berry, 1997; Berry \& Sam, 1996). Cabassa (2003) also proposed three main acculturation contexts (i.e., prior immigration context, immigration context, and settlement context), contending that attention to contextual factors would clarify the influencing mechanisms and forces on acculturation and would provide a more holistic view of the process. For instance, an individual who exhibits highly acculturated behaviors at school or work can simultaneously adhere to traditional cultural values at home in response to different expectations by his/her immediate surroundings. In addition, the acculturation/enculturation experiences in a rural community with few ethnic socialization or cultural learning resources are likely to differ from the experiences in an ethnically diverse metropolitan city. This contextual influence was well addressed in a seminal study by Berry, 
Phinney, Sam, and Vedder (2006), "International Comparative Study of Ethnocultural Youth," by looking at acculturation and adaptation of immigrant youths across 13 nations. They evaluated the diversity policy of the 13 nations on the basis of the nine criteria developed in a political science literature (e.g., a government policy promoting multiculturalism, adoption of multiculturalism in the school curriculum, ethnic representation in the media; Banting \& Kymlicka, as cited in Berry et al., 2006). Youths from highly supportive nations of cultural diversity (e.g., Australia, New Zealand) indicated positive correlations between ethnic and national identity; however, youths from less supportive nations (e.g., Germany) tended to reveal negative correlations between the two identities. These findings highlight the importance of a macro-context (e.g., diversity policy) for healthy integration of ethnic and national identity.

Overall, acculturation/enculturation contexts are multiplelayered (i.e., ranging from home to mainstream society) and vary in their proximity to and impact on an acculturating individual. Furthermore, these different levels of systems may interact with one another and exert unique influences on the acculturation/enculturation process. For example, if mainstream society has a highly supportive diversity policy, schools and parents may feel encouraged to facilitate children's bicultural development, whereas in the environments that adopt assimilation policies and devalue children's culture of origin, schools and parents may feel pressured to assimilate children into mainstream culture for children's survival and success, resulting in further loss of culture of origin and/or marginalization from both cultures. Thus, ecological perspectives are required to fully understand acculturation/enculturation experiences. In summary, we conceptualize acculturation/enculturation as a bilinear cultural socialization that proceeds across multiple dimensions through dynamic interactions between an individual and surrounding systems.

\section{Present Study}

On the basis of the aforementioned conceptualization of acculturation/enculturation, in the present study we systematically reviewed and evaluated counseling and counseling psychology literature that used acculturation and/or enculturation as a study

Journal of Counseling Psychology, Vol. 58, No. 1 (January 2011): pg. 83-96. DOI. This article is @ American Psychological Association and permission has been granted for this version to appear in e-Publications@Marquette. American Psychological Association does not grant permission for this article to be further copied/distributed or hosted elsewhere without the express permission from American Psychological Association. 
variable(s) in quantitative empirical research. Given the extensiveness of the acculturation literature, we restricted our analysis to the five major American Psychological Association (APA) and American Counseling Association (ACA) journals that represent the field of counseling and counseling psychology in general, multicultural counseling, and ethnic minority psychology: Journal of Counseling Psychology (JCP), The Counseling Psychologist (TCP), Journal of Counseling and Development (JCD), Journal of Multicultural Counseling and Development (JMCD), and Cultural Diversity and Ethnic Minority Psychology (CDEMP). We analyzed the patterns and trends of acculturation research in (a) conceptualization and use of acculturation/enculturation variable(s), (b) research designs (e.g., sample characteristics, instruments, data collection, and analysis methods), (c) content areas, and (d) changes in total publications and research trends over time. Additionally, we conducted meta-analyses on the relationship between acculturation/enculturation and a few key variables of mental health, adjustment, and well-being to present another way of synthesizing acculturation research.

\section{Method}

\section{Judges}

Two faculty members and one advanced doctoral student from two counseling psychology programs served as judges in this study. All three judges were Asian American women. The first author created initial coding categories and collected data, and all three judges participated in data analysis. After discussing the classification system and reviewing coding examples developed by the first author, each researcher evaluated about two thirds of all studies so that each study was reviewed by two researchers. Because of the geographic distance among judges, we used e-mails and phone calls in addition to face-toface communications to refine the classification system, discuss disagreements, and reach consensus. We calculated Cohen's kappa to check interrater agreement for the initial analysis. Results showed a satisfactory consistency of .91. We resolved remaining discrepancies through follow-up discussions. 
NOT THE PUBLISHED VERSION; this is the author's final, peer-reviewed manuscript. The published version may be accessed by following the link in the citation at the bottom of the page.

\section{Procedure}

We conducted a search of empirical studies on PsycINFO using the following keywords: acculturation, enculturation, cultural values, and acculturation gap. The initial search produced a total of 198 articles from JCP, TCP, JCD, JMCD, and CDEMP. We reviewed each article if it met the inclusion criteria of quantitative empirical research that used acculturation and/or enculturation as a study variable(s). Thus, qualitative research or studies that did not operationalize acculturation/enculturation as a study variable(s) were excluded, resulting in a total of 132 articles. We followed researchers' operationalization of acculturation and enculturation in deciding whether they were used as a study variable(s). For example, if a researcher used length of residence in the United States as an indicator of acculturation, we included the study for analysis. Cuéllar et al. (1995), Kim and Abreu (2001), and Schwartz et al. (2010) included ethnic identity as one area (dimension) of acculturation/enculturation. However, it also stands as an independent field of research. Thus, although we previously discussed ethnic identity in relation to different patterns and rates of acculturation/enculturation across multiple dimensions, we included ethnic identity studies only if ethnic identity was clearly operationalized as an indicator of acculturation/enculturation.

As a check on the thoroughness of the search strategy, we reviewed all the publications by the top seven researchers (the third through the seventh place researchers were tied with five publications each). This search located two additional articles that the keyword search could not find. The top seven researchers' names in the alphabetic order were Donald R. Atkinson, Lisa Y. Flores, Ruth Gim Chung, Bryan S. K. Kim, Frederick T. L. Leong, Lucila Ramos Sanchez, and Gargi Roysircar Sodowsky. They published 45 articles in total, composing $34.6 \%$ of the final data set. In summary, we identified a total of 138 studies in 134 articles, whose publication spanned from 1988 to 2009. Specifically, 41 articles were from $J C P$, two articles were from $T C P, 12$ articles were from $J C D, 19$ articles were from $J M C D$, and 64 studies in 60 articles were from CDEMP. The summary table of the characteristics and major findings of the 134 articles is presented in the Appendix located in the online supplemental materials.

Journal of Counseling Psychology, Vol. 58, No. 1 (January 2011): pg. 83-96. DOI. This article is @ American Psychological Association and permission has been granted for this version to appear in e-Publications@Marquette. American Psychological Association does not grant permission for this article to be further copied/distributed or hosted elsewhere without the express permission from American Psychological Association. 
Although the scope of this content analysis study was limited to the acculturation research in counseling and counseling psychology, we examined the relative position of the five target journals in the acculturation literature in general. By using the same keywords, the PsycINFO search resulted in 3,938 hits of empirical studies (i.e., including both quantitative and qualitative studies) published in peer reviewed journals. The top 10 journals with the most publications are presented in rank order in Table 1. CDEMP ranked third (96 hits), JCP ranked fifth (51 hits), and JMCD ranked 10 th (27 hits). JCD (16 hits) and TCP (eight hits) were not included in the top 10 journals. Overall, $5.0 \%$ of the total articles were published in the five target journals.

An initial classification system for content analysis was developed on the basis of our conceptualization of acculturation/enculturation as well as the examples of previous content analysis studies (e.g., Buboltz et al., 1999; Worthington, SothMcNett, \& Moreno, 2007). While inductively reviewing the studies, we further refined the classification system. First, we examined how acculturation/enculturation variable(s) was conceptualized and used. Specifically, we analyzed linearity (e.g., unilinear, bilinear); dimensionality (e.g., specific dimension scores vs. total scores); inclusion of acculturation contexts in research design; acculturation/enculturation as a continuous versus categorical variable; and its role as a predictor, outcome, mediator, moderator, and/or covariate. Second, we analyzed research designs including sample characteristics (e.g., race/ethnicity, sampling from kindergarten-12 schools, college, or community), instruments, study types (e.g., survey study, laboratory experiment, field experiment), data collection (e.g., language used), and analysis methods (i.e., statistical methods). Third, content areas were inductively developed by focusing on dependent variables. The content areas used in previous content analysis research were not applicable because they were developed either to review a specific journal (Buboltz et al., 1999) or to study different topics such as multicultural counseling competency (Worthington et al., 2007). Finally, we traced changes in total publications by counting the number of published articles from 1988 to 2009 in 2-year increments. We also traced changes in research trends across four different periods of 1988-1995, 19962000, 2001-2005, and 2006-2009 as to (a) conceptualization and use of acculturation/enculturation variable(s), (b) research designs, and 
(c) content areas. Additionally, we conducted meta-analyses on the relationships between acculturation/enculturation and a few key variables of mental health, adjustment, and well-being to explore another way of synthesizing acculturation/enculturation research (i.e., what has been found rather than how it has been found).

Although the total number of studies was 138 in 134 articles, the specific number of cases for each analysis varied. For example, if a study used two acculturation/enculturation measures, we analyzed how each measure was used, thus, $n$ exceeding 138. If a study used multiple main analysis methods, we analyzed all methods that involved acculturation/enculturation variable(s) ( $n=197)$. However, 134 articles rather than 138 studies were used to trace the number of total publications over years.

\section{Results}

\section{Conceptualization and Use of Acculturation/Enculturation Variable}

We evaluated linearity; dimensionality; inclusion of contexts in research design; use of acculturation/enculturation as a continuous versus categorical variable; and its role as a predictor, outcome, moderator, mediator, and/or covariate. As shown in Table 2, acculturation/enculturation was used more often as a unilinear $(44.4 \%)$ than a bilinear $(29.6 \%)$ construct. Total scores across dimensions $(62.3 \%)$ were preferred to scores of a specific dimension(s) (28.4\%). About half of these dimension scores were about values. Only four of 138 studies included social contexts of acculturation/enculturation in the research design. They examined the influence of historically Black versus White campus environments on enculturation levels (Cokley \& Helm, 2007), interaction between individual acculturation strategies and various social situations (Coleman, Casali, \& Wampold, 2001), acculturation levels of Vietnamese college students living in versus away from Vietnamese communities (Duan \& Vu, 2000), and acculturation levels of Asian American students in the United States versus Asian students in Asia (Suinn, Knoo, \& Ahuna, 1995). Acculturation/enculturation was used mostly as a continuous $(80.9 \%)$ rather than a categorical variable 
NOT THE PUBLISHED VERSION; this is the author's final, peer-reviewed manuscript. The published version may be accessed by following the link in the citation at the bottom of the page.

(e.g., Berry's typology of acculturation strategies, high vs. low acculturation; $17.3 \%)$ and also as a predictor $(69.4 \%)$.

\section{Research Design}

Table 3 presents sample characteristics, study types, and data collection and analysis methods. Except for a small number of cases $(8.1 \%)$ that either combined different racial groups together (e.g., Latino/as and Asian Americans) or did not specify racial/ethnic composition of a sample, most analyses were conducted separately for different racial or ethnic groups. The vast majority of the studies were conducted with Latino/as (30.4\%) or Asians/Asian Americans (51.4\%). European Americans (e.g., Greek, Italian, and Russian Americans), African Americans including recent immigrants, and Native Americans (e.g., Yup'ik tribe) accounted for only a small portion of the studies $(10.1 \%)$. As a single ethnic group, Mexican Americans were most frequently studied. Over half of the samples were recruited from college campuses ( $56.5 \%)$, followed by communities, kindergarten-12 schools, and other (e.g., outpatient mental health clinics, prisons, company workshops).

A total of 42 acculturation/enculturation scales were used after excluding proxy measures (e.g., age of immigration, length of residence in the United States). Table 4 presents the most frequently used measures, including the Suinn-Lew Asian Self-Identity Acculturation Scale (SL-ASIA; Suinn, Rickard-Figueroa, Lew, \& Vigil, 1987), the Asian Values Scale (AVS; Kim et al., 1999), the Acculturation Rating Scale for Mexican Americans (ARSMA; Cuéllar et al., 1980), and the Acculturation Rating Scale for Mexican AmericansII (ARSMA-II; Cuéllar et al., 1995). These four measures were used for almost half of all cases (49.1\%), whereas 22 measures were used only once.

As shown in Table 3, survey studies composed almost $90 \%$ of total studies. Although most of them used paper-and-pencil measures, 10 studies conducted interviews to collect survey data from community samples. Most studies were conducted only in English (86.3\%), even though a small number of studies either translated surveys or interviewed participants in their native languages to complete surveys

Journal of Counseling Psychology, Vol. 58, No. 1 (January 2011): pg. 83-96. DOI. This article is @ American Psychological Association and permission has been granted for this version to appear in e-Publications@Marquette. American Psychological Association does not grant permission for this article to be further copied/distributed or hosted elsewhere without the express permission from American Psychological Association. 
(e.g., Spanish, Chinese). The vast majority of studies collected data from the United States, and only three studies collected data from outside of the United States (i.e., Canada, Taiwan, Singapore). Correlations and regressions, especially hierarchical multiple regression, that did not involve moderation or mediation tests were the analysis methods of choice for almost half of all main analyses $(48.2 \%)$, followed by mean comparisons using $t$ tests or analyses of variance (e.g., analysis of variance, multivariate analysis of variance, analysis of covariance, multivariate analysis of covariance; $24.4 \%$ ). More complicated analyses included moderation tests by using analyses of variance or hierarchical multiple regressions, mediation tests by using multiple regressions, path analyses and structural equation modeling, and factor analyses.

\section{Content Areas}

We evaluated the content areas of the 138 studies focusing on dependent variables. The most widely studied areas were as follows: (a) help seeking attitudes (e.g., counselor preference, perceived counselor credibility or competence, willingness to seek counseling), $n$ $=33,23.9 \%$; (b) mental health, adjustment, and well-being (e.g., depression, anxiety, psychological distress, self-esteem, satisfaction with life), $n=29,21.0 \%$; (c) career/academic development (e.g., career self-efficacy, educational aspiration) $n=11,8.0 \%$; (d) acculturation/enculturation itself (e.g., construct structure, acculturation strategies, levels), $n=10,7.2 \%$; (e) health psychology (e.g., diabetes, Alzheimer's, breast cancer, HIV), $n=8,5.8 \%$; (f) acculturation/enculturation scale development and validation, $n=7$, $5.1 \%$; and $(\mathrm{g})$ other scale development and validation, $n=7,5.1 \%$. Other areas of research included family conflicts, parenting, problem solving and coping strategies, body images and eating attitudes, and so forth.

\section{Changes in Total Publications and Research Trends}

Figure 1 presents changes in the number of articles published from 1988 to 2009 in 2-year increments. In spite of some fluctuations, in general, the number of articles has increased from only four articles in $1988-1989$ to 25 articles in 2008-2009.

Journal of Counseling Psychology, Vol. 58, No. 1 (January 2011): pg. 83-96. DOI. This article is (C) American Psychological Association and permission has been granted for this version to appear in e-Publications@Marquette. American Psychological Association does not grant permission for this article to be further copied/distributed or hosted elsewhere without the express permission from American Psychological Association. 
Changes in research trends across four different periods of 1988-1995, 1996-2000, 2001-2005, and 2006-2009 indicated a decline of unilinear measures (e.g., SL-ASIA, ARSMA) and an increase of bilinear measures (e.g., ARSMA-II, Abbreviated Multidimensional Acculturation Scale) and enculturation only measures (e.g., AVS). For example, in 1988-1995, most studies used either SL-ASIA or ARSMA as a measure of choice ( $n=19$ of 26 cases, 73.1\%). However, in 2006-2009, SL-ASIA and ARSMA were never used. For the first time in 2005, bilinear measures outnumbered unilinear measures. As evidenced by the use of 27 different measures in 2006-2009, this period was characterized by diversification and proliferation of acculturation/enculturation measures. Until 2000, only total scores of acculturation/enculturation were used for most analyses ( $n=42$ of 51 cases, $82.4 \%$ ); after 2001, however, increasing number of studies paid attention to dimensional scores ( $n=48$ of 109 cases, $44.0 \%$ ). Acculturation/enculturation has been used mostly as a predictor across the four periods; however, after 2000, a slight increase was noticed in its role as a moderator or a mediator.

Sampling sources indicated a slight decline of college campuses (63.8\% vs. $52.2 \%$, until vs. after 2000) and an increase of community samples (10.9\% vs. 20.7\%, until vs. after 2000). As for study types, survey studies revealed a gradual increase from $77.1 \%$ to $85.0 \%$, $89.1 \%$, and $95.7 \%$ over the four periods. In spite of a slight increase in using languages other than English, most studies still used only English in data collection, which unfortunately limited data collection from certain ethnic communities. The most frequently used analysis methods have changed from mean comparisons (e.g., $n=23$ of 36 cases, 63.9\%, in 1988-1995) to correlations and regressions (e.g., $n$ $=36$ of 64 cases, 56.3\%, in 2006-2009) together with the increased use of acculturation/enculturation as a continuous over categorical variable. More sophisticated analysis methods of moderation and mediation tests, path analyses, and structural equation modeling increased since the early 2000s.

The content areas of acculturation/enculturation research have also shifted from help seeking attitudes to mental health, adjustment, and well-being. In 1988-1995, the top area of interest was help seeking attitudes ( $n=13$ of 26 cases, 50.0\%); in 1996-2000, help seeking attitudes ( $n=3$ of 20 cases, 15.0\%); in 2001-2005, mental 
health, adjustment, and well-being ( $n=12$ of 43 cases, 27.9\%); and in 2006-2009, mental health, adjustment, and well-being ( $n=14$ of 46 cases, $30.4 \%$ ). No noticeable changes were detected as to the inclusion of social contexts or racial/ethnic composition of samples.

\section{Meta-Analyses}

\section{Selection of studies}

Given the wide range of content areas and associated variables in the 138 studies, it was impossible to conduct meta-analyses for all variables associated with acculturation and enculturation. Thus, we limited our meta-analyses to the relationship between acculturation/enculturation and mental health, adjustment, and wellbeing-an area that counselors and counseling psychologists may be most interested in. The review of 29 studies in this content area indicated a host of variables associated with acculturation/enculturation (e.g., psychological distress, depression, anxiety, suicidal behavior, self-esteem, life satisfaction, positive affect, negative affect). The associations between acculturation/enculturation and the top two most frequently studied variables were decided for meta-analyses: acculturation and psychological distress/depression ( $k$ $=12)$, enculturation and psychological distress/depression $(k=10)$, acculturation and self-esteem $(k=4)$, and enculturation and selfesteem $(k=5)$. The studies met the following inclusion criteria: (a) selection of participants in the United States and (b) use of acculturation/enculturation as continuous variables. Table 5 describes the studies included in the meta-analyses.

\section{Random effects models}

We used random effects models because they make inferences about a population of studies beyond the present sample of studies by considering both within-study and between-study variability. Accordingly, they are more conservative (i.e., hard to reject null hypotheses) than fixed effects models (Lipsey \& Wilson, 2001). In addition, several significant $Q$ statistics in the tests of homogeneity of effect sizes recommended random effects models: (a) acculturation and psychological distress/depression, $Q(11)=49.58, p<.001$; (b) 
enculturation and psychological distress/depression, $Q(9)=11.38, p$ $>.05$; (c) acculturation and self-esteem, $Q(3)=22.66, p<.001$; and (d) enculturation and self-esteem, $Q(4)=10.62, p<.05$.

\section{Effect size calculation}

The correlation coefficient (i.e., $r$ ) was the effect size measure of choice. For each meta-analysis, only one effect size was included from each study. For example, when multiple relevant correlations were reported from the same sample (e.g., Wong, Tran, \& Lai, 2009), the average of the correlations was coded as the effect size. When the correlation was reported for each subgroup of the sample (e.g., Yeh, 2003), the correlation with the overall sample was coded as the effect size. When the correlations for both acculturation/enculturation total scales and dimensions were reported, we chose the correlations with total scales (e.g., Obasi \& Leong, 2009). Four studies reported only standardized regression weights without any information to calculate correlations (e.g., Cavazos-Rehg \& DeLucia-Waack, 2009; Rahman \& Rollock, 2004; Rodriguez, Mira, Morris, \& Cardoza, 2003; Tsai et al., 2000). Following Hunter and Schmidt's (2004) claim that standardized regression weights could validly substitute for correlations in metaanalyses, we used standardized regression weights for the four studies (see Poropat, 2009). To avoid any problem associated with the standard error formulation of correlation coefficients, we converted each effect size of $r$ to $z r$ by using Fisher's $r$-to- $z$ transformation to calculate the $Q$ statistic for homogeneity test and the mean effect size. To adjust for the heterogeneity of variance across studies, we weighted each effect size by the inverse variance that was based on the sample size. Finally, the mean effect size of $z r$ was backtransformed to report the mean effect size of $r$ and its confidence interval (see Hedges \& Olkin, 1985; Lipsey \& Wilson, 2001).

\section{Results}

The first meta-analysis included the 12 studies $(N=2,023)$ that examined the relationship of acculturation and psychological distress/depression. The mean effect size of the correlations was nonsignificant $(r=-.07, p>.05,95 \%$ CI $[-.17, .03])$. Second, the mean effect size of the 10 studies $(N=1,751)$ that examined the 
association of enculturation and psychological distress/depression was nonsignificant $(r=.04, p>.05,95 \%$ CI $[-.01, .08])$. Third, the mean effect size of the four studies $(N=1,181)$ revealed a nonsignificant relationship between acculturation and self-esteem $(r=.10, p>.05$, $95 \%$ CI $[-.06, .26])$. Finally, the mean effect size of the five studies $(N=1,325)$ revealed a nonsignificant relationship between enculturation and self-esteem $(r=.09, p>.05,95 \%$ CI $[-.00, .18])$.

No systematic variations in the relationship of acculturation/enculturation and psychological distress/depression or self-esteem were detected by measures or sampling sources. However, Obasi and Leong's (2009) study, which was the only study conducted with African Americans, revealed a moderately significant positive relationship between acculturation and psychological distress $(r=.28)$. This finding was contradictory to the findings of the other studies that indicated either nonsignificant or negative associations between the two variables. Thus, we conducted a new meta-analysis after excluding Obasi and Leong's study, which revealed a significantly negative association between acculturation and psychological distress/depression $(r=-.10, p<.05,95 \%$ CI $[-.19,-.02])$.

\section{Discussion}

In the present study, we evaluated 138 quantitative empirical studies in five major APA and ACA journals in counseling and counseling psychology that used acculturation and/or enculturation as a study variable(s). As a theoretical and conceptual framework for the content analysis, we delineated acculturation/enculturation as a "bilinear," "multidimensional" cultural socialization process that occurs in interaction with "social contexts." Unilinear measures of acculturation/enculturation-especially ARSMA for Latino/as and SLASIA for Asian Americans-were most frequently used until recently. However, with increasing awareness of theoretical and measurement problems with unilinear measures (Abe-Kim et al., 2001; Cuéllar et al., 1995; Kim \& Abreu, 2001; Miller, 2007), more studies have selected bilinear rather than unilinear measures since 2005.

Even though recent research has paid attention to specific dimensions of acculturation/enculturation (e.g., values; Kim, 2007; 
Kim, Ng, \& Ahn, 2009), the field, in general, has not yet advanced to examine how various aspects of acculturation/enculturation are differently related to one another or to outcome variables of interest. Furthermore, although the importance of acculturation contexts has been emphasized ever since Berry's literature in the 1980s, social contexts have rarely been included in research designs as a study variable beyond conceptual discussion, revealing a gap between theoretical/conceptual development and empirical research. Although acculturation/enculturation is an evolving process through interactions between individuals and multiple layers of surrounding systems rather than a static status or inherent traits, few studies captured the dynamic, interactive, and developing nature of acculturation/enculturation. Instead, most studies measured acculturation/enculturation levels at a given point and examined their relationship with other variables discounting contextual factors.

The majority of the studies were conducted with Latino/as or Asian Americans, and only a small number of studies included European Americans, African Americans, or Native Americans. This distinction in sampling is a long-standing phenomenon in multicultural counseling literature. Acculturation/enculturation and racial/ethnic identity are two key variables to understand within minority group variability, whereas sociopolitical dynamics and cultural differences are two perspectives to approach multicultural counseling. Racial identity research has focused on sociopolitical aspects in multicultural counseling, mostly with European Americans and African Americans (Helms, 2007; Ponterotto \& Park-Taylor, 2007), whereas ethnic identity and acculturation/enculturation research has focused on cultural aspects, mostly with Latino/as and Asian Americans whose immigration histories are relatively short (Cokley, 2007; Yoon, 2010). However, regardless of their generational status in the United States, cultural socialization and adjustment are relevant issues to any racial/ethnic groups who should function in more than one cultural context. Interestingly, contrary to the previous findings in favor of integration as an acculturation strategy of choice (Berry, 1997), Obasi and Leong's (2009) study with African Americans revealed that integration was the worst and separation was the best acculturative strategy in relation to psychological distress. Considering African Americans' history as the oppressed, reactive ethnicity, stronger adherence to one's own culture to cope with discrimination may 
partially explain this result (Rumbaut; cited in Schwartz et al., 2010). Thus, to further advance the acculturation field, future research should examine how racial/ethnic group specific variables of racism experiences, socioeconomic force, and political voice interact with acculturation/enculturation process by expanding the research to European Americans, African Americans, and Native Americans beyond Latino/as or Asian Americans.

College students accounted for over half of all study samples in spite of the fact that they respectively represent only approximately $1 \%$ and $3 \%$ of the general populations of Latino/as and Asian Americans (see U.S. Census Bureau, 2008). A content analysis of 26year research in JCP discovered a similar sample characteristic (Buboltz et al., 1999). Furthermore, over $85 \%$ of the studies used only English for data collection despite the fact that over $75 \%$ of Latino/as and Asian Americans speak a language other than English at home (U.S. Census Bureau, 2007a, 2007b). To diversify data collection sources and understand acculturation/enculturation experiences in the full spectrum, researchers should enter ethnic communities, build relationships, and conduct research in their native languages. Barriers to these attempts may include the following: (a) lack of researchers who can enter ethnic communities and conduct research in their native languages (Yoon, Lee, Koo, \& Yoo, 2010); (b) difficulties in translating, developing, and/or cross-culturally validating measures in research participants' native languages (Mallinckrodt \& Wang, 2004); and (c) cost (i.e., time, money, effort) involved in these extra steps. In addition, journal editors and reviewers as well as researchers, who are familiar with college student samples to understand universal human experiences or at least general group experiences, may question the relevance of the experiences of a specific ethnic group in the community (e.g., Haiti immigrants, Hmong refugees) to their readership, thus, deterring publication of research conducted in a specific ethic community. However, generalization can be achieved by extracting common denominators from culture specific experiences rather than by using conventional convenience samples.

The most typical type of study from this review was a survey study examining a direct relationship between acculturation/enculturation and such outcome variable(s) as help seeking attitudes and mental health, adjustment, and well-being by 
using hierarchical multiple regressions. To better comprehend the complexity of acculturation/enculturation experiences, recently more sophisticated research designs were developed that included moderators/mediators and that used path analysis or structural equation modeling. It appears that the field is starting to shift from examination of a simple, direct relationship between acculturation/enculturation and an outcome variable(s) of interest to exploration of more complicated relationships with acculturation/enculturation. It is also encouraging that approximately 300 researchers and more than 100 institutions contributed to the 134 articles. The broad base of acculturation researchers promises richness and creativity for future research.

Meta-analyses were additionally conducted to explore another way of reviewing acculturation/enculturation research-statistical syntheses. However, the sampling strategy left far too many studies by including only a small number of studies from a limited body of literature (i.e., five major journals) and by excluding publications in other journals, dissertations, or unpublished manuscripts. Given the incomprehensive sampling strategy in addition to the low power due to the small sample sizes, the findings from this exploratory attempt should be understood as statistical syntheses of the studies involved in the current research and a tentative conclusion to inform directions for future research. It is misleading to interpret the findings from this small, nonrepresentative sample of studies as a firm conclusion and to overgeneralize them to practice and research.

With these caveats in mind, acculturation indicated small negative effects on psychological distress and depression $(r=-.07)$ and a small positive effect on self-esteem $(r=.10)$, although these effect sizes marginally failed to reach statistical significance. Enculturation also indicated a small positive, but nonsignificant, effect on self-esteem $(r=.09)$. In fact, the counternull values for these nonsignificant findings (i.e., $r s=-.14, .20$, and .18) are as likely to be the true mean effect sizes as 0 (see Quintana \& Minami, 2006). Thus, the potentially positive effects of acculturation and enculturation on different aspects of mental health, adjustment, and well-being should be further examined in future meta-analyses based on a comprehensive review of literature. As to the potentially beneficial effects of acculturation on adjustment, two independent studies 
conducted in reversed cultural contexts revealed an interesting finding: (a) Chinese/Taiwanese international students in the United States (Wang \& Mallinckrodt, 2006) and (b) North American sojourners in Taiwan (Swagler \& Jome, 2005). Both studies indicated positive effects of acculturation to host cultures on psychological and sociocultural adjustment, which suggests the instrumental values of acculturation for adjustment in new cultures rather than intrinsic merits of specific cultures (i.e., U.S. mainstream or Chinese culture).

The scales to measure psychological distress and depression included the Brief Symptom Inventory (Derogatis, 1993), the Hopkins Symptom Check List (Green, Walkey, McCormick, \& Taylor, 1988), the Outcome Questionnaire-45 (Lambert et al., 1996), the Symptom Checklist-90-Revised (Derogatis, Rickels, \& Rock, 1976), the Beck Depression Inventory (Beck, Ward, Mendelson, Mock, \& Erbaugh, 1961), the Center for Epidemiological Studies-Depression (Radloff, 1977), the Hamilton Depression Inventory (Hamilton, 1960), and the Reynolds Adolescent Depression Scale-2 (Reynolds, 2002). The Rosenberg Self-Esteem Scale (Rosenberg, 1965) was used to measure self-esteem. The samples encompassed adolescents, college students, and community-based adults and were mostly Latino/as and Asians/Asian Americans.

Although no systematic variations in the relationship of acculturation/enculturation and mental health, adjustment, and wellbeing were detected by measures or sampling sources, the fact that the only study that was conducted with African Americans revealed a moderately significant positive relationship between acculturation and psychological distress/depression, contrary to other studies, is noteworthy. In fact, when we conducted a new meta-analysis after excluding this study, it revealed a significantly negative relationship between acculturation and psychological distress/depression. It is plausible that African Americans' group specific experiences of racism and oppression may have contributed to the development of a unique relationship between mental health and the mainstream cultural orientation. Adopting the mainstream culture is likely to have negative effects on mental health, especially for African Americans, if it was not accompanied with firmly understanding the psychological effects of racism, working through internalized racism, and developing healthy racial/cultural identity. This finding highlights the need to examine 
various moderators to explore possible systematic variations in the relationship between acculturation/enculturation and mental health variables. Potential moderators include demographic and sociocultural factors such as racial/ethnic groups, age of immigration, generational status, voluntary immigration versus involuntary subjugation, and acculturation/enculturation context.

The current study has several limitations. First, the classification system used for this study reflects researchers' biases. Other researchers may develop different classification systems on the basis of their conceptualization of acculturation/enculturation and important factors in acculturation/enculturation research (see Buboltz et al., 1999). Considering that all researchers were Asian Americans and that the current acculturation literature in counseling and counseling psychology is mostly built on Latino/as' and Asian Americans' experiences, the present study may reflect certain cultural biases. Second, given the extensive outlet for acculturation research and the difficulty in sorting out publications only by counseling and counseling psychology researchers, we selected five major APA and ACA journals that represent counseling and counseling psychology field in general, multicultural counseling, and ethnic minority psychology. Thus, this study could not encompass all acculturation/enculturation research by counseling and counseling psychology researchers. For example, possible publications by counseling and counseling psychology researchers in racial/ethnic group specific journals were not included (e.g., Asian American Journal of Psychology, Hispanic Journal of Behavioral Sciences, and Journal of Black Psychology). Given the high number of acculturation research published in Hispanic Journal of Behavioral Sciences, the current study entails a sampling bias. In addition, although many counseling psychologists contribute to CDEMP because of their discipline specific interest in diversity issues, CDEMP also includes publications from other disciplines of psychology (e.g., clinical psychology, social psychology). Lastly, this study limited its inclusion to quantitative studies. Although the growing body of qualitative studies has provided valuable information to the literature, qualitative studies were excluded because they could not fit into the quantitative framework of the present study. Thus, the findings of the current study should be understood with these limitations in mind. 
Although the primary purpose of this study was to provide a historical perspective by reviewing how the field has evolved, directions for future research were inferred from the review.

Suggestions for future acculturation/enculturation research include the following: (a) development of bilinear, multidimensional measures; (b) use of dimension specific scores in addition to total scores; (c) inclusion of contextual factors in research design (e.g., home, school, work, ethnic density, diversity policy); (d) examination of interaction among surrounding systems as well as between individuals and contexts (e.g., relationship among community diversity climate, parents' cultural socialization practice, and children's bicultural competency); (e) inclusion of racial/ethnic groups beyond Latino/as and Asian Americans (e.g., African Americans, Native Americans); (f) diversification in understanding acculturation experiences (e.g., European Americans' acculturation to ethnic minority cultures, ethnic minority individuals' acculturation to other minority cultures); (g) use of diverse samples including native language speaking adults in the community; (h) sophistication of research designs beyond a simple, direct relationship of acculturation/enculturation and an outcome variable(s) of interest (e.g., mediators of the relationship of acculturation/enculturation and mental health; interplay of culture, gender, and class); and (i) longitudinal studies to trace acculturation/enculturation process over time and generations. In addition, qualitative studies will allow themes related to acculturation/enculturation experiences to naturally emerge from participants with less imposed assumptions by researchers. Finally, the current content analysis study focused on how acculturation/enculturation research has been conducted, whereas extensive meta-analyses on each content area of acculturation/enculturation research, by including demographic and sociocultural moderating factors, will illuminate what has been found. Given the proliferation of acculturation/enculturation literature during the past few decades, a grand theory to update Berry's theory of acculturation is expected to synthesize current advancement in the field and to provide a theoretical framework for future research. 
NOT THE PUBLISHED VERSION; this is the author's final, peer-reviewed manuscript. The published version may be accessed by following the link in the citation at the bottom of the page.

\section{Notes}

- Eunju Yoon and Kimberly Langrehr, Counseling Psychology Program, Loyola University Chicago; Lee Za Ong, Department of Counselor Education and Counseling Psychology, Marquette University.

- We thank David Yoon for his assistance with data analysis.

- Correspondence concerning this article should be addressed to Eunju Yoon, Counseling Psychology Program, Loyola University Chicago, 820 North Michigan Avenue, Chicago, IL 60611. E-mail: eyoon@luc.edu

\section{References}

Abe-Kim, J., Okazaki, S., \& Goto, S. G. (2001). Unidimensional versus multidimensional approaches to the assessment of acculturation for Asian American populations. Cultural Diversity and Ethnic Minority Psychology, 7, 232-246. doi:10.1037/1099-9809.7.3.232

Arnett, J. J. (1995). Broad and narrow socialization: The family in the context of a cultural theory. Journal of Marriage and the Family, 57, 617-628. doi: $10.2307 / 353917$

Beck, A. T., Wand, C. H., Mendelson, M., Mock, L., \& Erbaugh, J. (1961). An inventory for measuring depression. Archives of General Psychiatry, 4, 561-571.

Berry, J. W. (1980). Social and cultural change. In H. C.Triandis \& R.Brislin (Eds.), Handbook of cross-cultural psychology: Social psychology (Vol. 5, pp. 211-279). Boston, MA: Allyn \& Bacon.

Berry, J. W. (1994). Acculturation and psychological adaptation: An overview. In A.Bouvy, F. J. R.Van de Vijver, P.Boski, \& P.Schmitz (Eds.), Journeys into cross-cultural psychology (pp. 129-141). Berwyn, PA: Swets \& Zeitlinger.

Berry, J. W. (1995). Psychology of acculturation. In N. R.Goldberger \& J. B.Veroff (Eds.), The culture and psychology reader (pp. 457-488). New York, NY: New York University Press.

Berry, J. W. (1997). Immigration, acculturation, and adaptation. Applied Psychology, 46, 5-34.

Berry, J. W., Phinney, J. S., Sam, D. L., \& Vedder, P. (Eds.). (2006). Immigrant youth in cultural transition. Mahwah, NJ: Erlbaum.

Journal of Counseling Psychology, Vol. 58, No. 1 (January 2011): pg. 83-96. DOI. This article is @ American Psychological Association and permission has been granted for this version to appear in e-Publications@Marquette. American Psychological Association does not grant permission for this article to be further copied/distributed or hosted elsewhere without the express permission from American Psychological Association. 
NOT THE PUBLISHED VERSION; this is the author's final, peer-reviewed manuscript. The published version may be accessed by following the link in the citation at the bottom of the page.

Berry, J. W., \& Sam, D. L. (1996). Acculturation and adaptation. In J. W.Berry, M. H.Segall, \& C.Kagitcibasi (Eds.), Handbook of crosscultural psychology: Social behavior and applications (Vol. 3, pp. 291326). Boston, MA: Allyn \& Bacon.

Birman, D., \& Taylor-Ritzler, T. (2007). Acculturation and psychological distress among adolescent immigrants from the former Soviet Union: Exploring the mediating effect of family relationships. Cultural Diversity and Ethnic Minority Psychology, 13, 337-346. doi:10.1037/1099-9809.13.4.337

Buboltz, W. C., Jr., Miller, M., \& Williams, D. J. (1999). Content analysis of research in the Journal of Counseling Psychology (1973-1998). Journal of Counseling Psychology, 46, 496-503. doi:10.1037/00220167.46.4.496

Cabassa, L. J. (2003). Measuring acculturation: Where we are and where we need to go. Hispanic Journal of Behavioral Sciences, 25, 127-146. doi: $10.1177 / 0739986303025002001$

Castillo, L. G., Conoley, C. W., \& Brossart, D. F. (2004). Acculturation, White marginalization, and family support as predictors of perceived distress in Mexican American female college students. Journal of Counseling Psychology, 51, 151-157. doi:10.1037/0022-0167.51.2.151

Cavazos-Rehg, P. A., \& DeLucia-Waack, J. L. (2009). Education, ethnic identity, and acculturation as predictors of self-esteem in Latino adolescents. Journal of Counseling and Development, 87, 47-54.

Céspedes, Y. M., \& Huey, S. J., Jr. (2008). Depression in Latino adolescents: A cultural discrepancy perspective. Cultural Diversity and Ethnic Psychology, 14, 168-172. doi:10.1037/1099-9809.14.2.168

Cokley, K. O. (2007). Critical issues in the measurement of ethnic and racial identity: A referendum on the state of the field. Journal of Counseling Psychology, 54, 224-234. doi:10.1037/0022-0167.54.3.224

Cokley, K., \& Helm, K. (2007). The relationship between African American enculturation and racial identity. Journal of Multicultural Counseling and Development, 35, 142-153.

Journal of Counseling Psychology, Vol. 58, No. 1 (January 2011): pg. 83-96. DOI. This article is @ American Psychological Association and permission has been granted for this version to appear in e-Publications@Marquette. American Psychological Association does not grant permission for this article to be further copied/distributed or hosted elsewhere without the express permission from American Psychological Association. 
NOT THE PUBLISHED VERSION; this is the author's final, peer-reviewed manuscript. The published version may be accessed by following the link in the citation at the bottom of the page.

Coleman, H. L. K., Casali, S. B., \& Wampold, B. E. (2001). Adolescent strategies for coping with cultural diversity. Journal of Counseling and Development, 79, 356-364.

Cuéllar, I., Arnold, B., \& Maldonado, R. (1995). Acculturation Rating Scale for Mexican Americans-II: A revision of the original ARSMA scale. Hispanic Journal of Behavioral Sciences, 17, 275-304. doi: $10.1177 / 07399863950173001$

Cuéllar, I., Harris, L. C., \& Jasso, R. (1980). An acculturation scale for Mexican American normal and clinical populations. Hispanic Journal of Behavioral Sciences, 2, 199-217.

Derogatis, L. R. (1993). Brief Symptom Inventory: Administration, scoring, and procedures manual. Minneapolis, MN: National Computer Systems.

Derogatis, L. R., Rickels, K., \& Rock, A. F. (1976). The Symptom Checklist-90 and the MMPI: A step in the validation of a new self-report scale.

British Journal of Psychiatry, 128, 280-289.

doi:10.1192/bjp.128.3.280

Duan, C., \& Vu, P. (2000). Acculturation of Vietnamese students living in or away from Vietnamese communities. Journal of Multicultural Counseling and Development, 28, 225-242.

Giang, M. T., \& Wittig, M. A. (2006). Implications of adolescents' acculturation strategies for personal and collective self-esteem. Cultural Diversity and Ethnic Minority Psychology, 12, 725-739. doi:10.1037/10999809.12.4.725

Gim Chung, R. H., Kim, B. S. K., \& Abreu, J. M. (2004). Asian American Multidimensional Acculturation Scale: Development, factor analysis, reliability, and validity. Cultural Diversity and Ethnic Minority Psychology, 10, 66-80. doi:10.1037/1099-9809.10.1.66

González, G. M., Costello, C. R., Toutello, C. R., Joyce, L. K., \& Valensuela, M. (1997). Bilingual telephone-assisted computerized speech-recognition assessment: Is a voice-activated computer program a culturally and linguistically appropriate tool for screening depression in English and Spanish?Cultural Diversity and Mental Health, 3, 93-111.

doi:10.1037/1099-9809.3.2.93

Journal of Counseling Psychology, Vol. 58, No. 1 (January 2011): pg. 83-96. DOI. This article is @ American Psychological Association and permission has been granted for this version to appear in e-Publications@Marquette. American Psychological Association does not grant permission for this article to be further copied/distributed or hosted elsewhere without the express permission from American Psychological Association. 
NOT THE PUBLISHED VERSION; this is the author's final, peer-reviewed manuscript. The published version may be accessed by following the link in the citation at the bottom of the page.

Graves, T. D. (1967). Acculturation, access, and alcohol in a tri-ethnic community. American Anthropologist, 69, 306-321.

doi:10.1525/aa.1967.69.3-4.02a00030

Green, D. E., Walkey, F. H., McCormick, I. A., \& Taylor, J. W. (1988). Development and evaluation of a 21 Item version of the Hopkins Symptom Checklist with New Zealand and United States respondents. Australian Journal of Psychology, 40, 61-70. doi:10.1080/00049538808259070

Hamilton, M. (1960). A rating scale for depression. Journal of Neurology, Neurosurgery, and Psychiatry, 23, 56-62. doi:10.1136/jnnp.23.1.56

Heath, A. E., Neimeyer, G. J., \& Pedersen, P. B. (1988). The future of crosscultural counseling: A Delphi poll. Journal of Counseling and Development, 67, 27-30.

Hedges, L. V., \& Olkin, I. (1985). Statistical methods for meta-analysis. Orlando, FL: Academic Press.

Helms, J. E. (2007). Some better practices for measuring racial and ethnic identity constructs. Journal of Counseling Psychology, 54, 235-246. doi:10.1037/0022-0167.54.3.235

Hong, J., \& Min, P. G. (1999). Ethnic attachment among second generation Korean Americans. Amerasia Journal, 25, 165-178.

Hong, S., Kim, B. S. K., \& Wolfe, M. M. (2005). A psychometric revision of the European American Values Scale for Asian Americans using the Rasch model. Measurement and Evaluation in Counseling and Development, 37, 194-207.

Hunter, J. E., \& Schmidt, F. L. (2004). Methods of meta-analysis: Correcting error and bias in research findings. Thousand Oaks, CA: Sage.

Hwang, W., \& Ting, J. Y. (2008). Disaggregating the effects of acculturation and acculturative stress on the mental health of Asian Americans. Cultural Diversity and Ethnic Minority Psychology, 14, 147-154. doi:10.1037/1099-9809.14.2.147

Kim, B. S. K. (2007). Adherence to Asian and European American cultural values and attitudes toward seeking professional psychological help

Journal of Counseling Psychology, Vol. 58, No. 1 (January 2011): pg. 83-96. DOI. This article is @ American Psychological Association and permission has been granted for this version to appear in e-Publications@Marquette. American Psychological Association does not grant permission for this article to be further copied/distributed or hosted elsewhere without the express permission from American Psychological Association. 
NOT THE PUBLISHED VERSION; this is the author's final, peer-reviewed manuscript. The published version may be accessed by following the link in the citation at the bottom of the page.

among Asian American college students. Journal of Counseling Psychology, 54, 474-480. doi:10.1037/0022-0167.54.4.474

Kim, B. S. K., \& Abreu, J. M. (2001). Acculturation measurement: Theory, current instruments, and future directions. In J. G.Ponterotto, J. M.Casa, L.Suzuki, \& C. M.Alexander (Eds.), Handbook of multicultural counseling (2nd ed., pp. 394-424). Thousand Oaks, CA: Sage.

Kim, B. S. K., Atkinson, D. R., \& Umemoto, D. (2001). Asian cultural values and the counseling process: Current knowledge and directions for future research. The Counseling Psychologist, 29, 570-603. doi: $10.1177 / 0011000001294006$

Kim, B. S. K., Atkinson, D. R., \& Yang, P. H. (1999). The Asian Values Scale: Development, factor analysis, validation, and reliability. Journal of Counseling Psychology, 46, 342-352. doi:10.1037/00220167.46.3.342

Kim, B. S., Li, L. C., \& Ng, G. F. (2005). The Asian American Values ScaleMultidimensional: Development, reliability, and validity. Cultural Diversity and Ethnic Minority Psychology, 11, 187-201. doi:10.1037/1099-9809.11.3.187

Kim, B. S. K., Ng, G. F., \& Ahn, A. J. (2009). Client adherence to Asian cultural values, common factors in counseling, and session outcome with Asian American clients at a university counseling center. Journal of Counseling and Development, 87, 131-142.

LaFromboise, T., Coleman, H. L. K., \& Gerton, J. (1993). Psychological impact of biculturalism: Evidence and theory. Psychological Bulletin, 114, 395-412. doi:10.1037/0033-2909.114.3.395

Lambert, M. J., Hansen, N. B., Umpress, V., Lunnen, K., Okiishi, J., Burlingame, G. M., \& Reisinger, C. R. (1996). Administration and scoring manual for the Outcome Questionnaire (OQ-45). Stevenson, MD: American Professional Credentialing Services.

Lee, R. M., Yoon, E., \& Liu-Tom, H. T. (2006). Structure and measurement of acculturation/enculturation for Asian Americans using the ARSMA-II. Measurement and Evaluation in Counseling and Development, 39, 4255. 
NOT THE PUBLISHED VERSION; this is the author's final, peer-reviewed manuscript. The published version may be accessed by following the link in the citation at the bottom of the page.

Lipsey, M. W., \& Wilson, D. B. (2001). Practical meta-analysis. Thousand Oaks, CA: Sage.

Mallinckrodt, B., \& Wang, C. (2004). Quantitative methods for verifying semantic equivalence of translated research instruments: A Chinese version of the experiences in close relationships scale. Journal of Counseling Psychology, 51, 368-379. doi:10.1037/00220167.51.3.368

Marin, G., \& Gamba, R. J. (1996). A new measurement of acculturation for Hispanics: The Bidimensional Acculturation Scale for Hispanics (BAS). Hispanic Journal of Behavioral Sciences, 18, 297-316. doi:10.1177/07399863960183002

Marin, G., Sabogal, F., Marin, B. V., Otero-Sabogal, R., \& Perez-Stable, E. J. (1987). Development of a short acculturation scale for Hispanics. Hispanic Journal of Behavioral Sciences, 9, 183-205. doi:10.1177/07399863870092005

Mendoza, R. H. (1989). An empirical scale to measure type and degree of acculturation in Mexican-American adolescents and adults. Journal of Cross-Cultural Psychology, 20, 372-385. doi: $10.1177 / 0022022189204003$

Miller, M. J. (2007). A bilinear multidimensional measurement model of Asian American acculturation and enculturation: Implications for counseling interventions. Journal of Counseling Psychology, 54, 118-131. doi: 10.1037/0022-0167.54.2.118

Moradi, B., \& Risco, C. (2006). Perceived discrimination experiences and mental health of Latina/o American persons. Journal of Counseling Psychology, 53, 411-421. doi:10.1037/0022-0167.53.4.411

Obasi, E. M., \& Leong, F. T. (2009). Psychological distress, acculturation, and mental health-seeking attitudes among people of Africa descent in the United States: A preliminary investigation. Journal of Counseling Psychology, 56, 227-238. doi:10.1037/a0014865

Oetting, E. R., \& Beauvais, F. (1990-1991). Orthogonal cultural identification theory: The cultural identification of minority adolescents. International Journal of the Addictions, 25, 655-685.

Journal of Counseling Psychology, Vol. 58, No. 1 (January 2011): pg. 83-96. DOI. This article is @ American Psychological Association and permission has been granted for this version to appear in e-Publications@Marquette. American Psychological Association does not grant permission for this article to be further copied/distributed or hosted elsewhere without the express permission from American Psychological Association. 
NOT THE PUBLISHED VERSION; this is the author's final, peer-reviewed manuscript. The published version may be accessed by following the link in the citation at the bottom of the page.

Olvera, A. E. P., Stewart, S. M., Galindo, L., \& Stephens, J. (2007). Diabetes, depression, and metabolic control in Latinas. Cultural Diversity and Ethnic Minority Psychology, 13, 225-231. doi:10.1037/10999809.13.3.225

Phinney, J. (2003). Ethnic identity and acculturation. In K. M.Chun, P.Balls Organista, \& G.Marin (Eds.), Acculturation: Advances in theory, measurement, and applied research (pp. 63-81). Washington, DC: American Psychological Association. doi:10.1037/10472-006

Ponterotto, J. G., Baluch, S., \& Carielli, D. (1998). The Suinn-Lew Asian SelfIdentity Acculturation Scale (SL-ASIA): Critique and research recommendations. Measurement and Evaluation in Counseling and Development, 31, 109-124.

Ponterotto, J. G., \& Park-Taylor, J. (2007). Racial and ethnic identity theory, measurement, and research in counseling psychology: Present status and future direction. Journal of Counseling Psychology, 54, 282-294. doi: $10.1037 / 0022-0167.54 .3 .282$

Poropat, A. E. (2009). A meta-analysis of the five-factor model of personality and academic performance. Psychological Bulletin, 135, 322-338.

Quintana, S. M., \& Minami, T. (2006). Guidelines for meta-analyses of counseling psychology research. The Counseling Psychologist, 34, 839-877. doi:10.1177/0011000006286991

Radloff, L. (1977). The CES-D scale: A self-report depression scale for research in the general population. Applied Psychological Measurement, 1, 385-401. doi:10.1177/014662167700100306

Rahman, O., \& Rollock, D. (2004). Acculturation, competence, and mental health among South Asian students in the United States. Journal of Multicultural Counseling and Development, 32, 130-142.

Redfield, R., Linton, R., \& Herskovits, M. J. (1936). Memorandum on the study of acculturation. American Anthropologist, 56, 149-152.

Reynolds, W. M. (2002). Reynolds Adolescent Depression Scale-2: Professional manual. Odessa, FL: Psychological Assessment Resources.

Rodriguez, N., Mira, C. B., Morris, J. K., \& Cardoza, D. (2003). Family or friends: Who plays a greater supportive role for Latino college

Journal of Counseling Psychology, Vol. 58, No. 1 (January 2011): pg. 83-96. DOI. This article is @ American Psychological Association and permission has been granted for this version to appear in e-Publications@Marquette. American Psychological Association does not grant permission for this article to be further copied/distributed or hosted elsewhere without the express permission from American Psychological Association. 
NOT THE PUBLISHED VERSION; this is the author's final, peer-reviewed manuscript. The published version may be accessed by following the link in the citation at the bottom of the page.

students?Cultural Diversity and Ethnic Minority Psychology, 9, 236250. doi:10.1037/1099-9809.9.3.236

Rosenberg, M. (1965). Society and the adolescent self-image. Princeton, NJ: Princeton University Press.

Rudmin, F. W. (2003). Critical history of the acculturation psychology of assimilation, separation, integration, and marginalization, Review of General Psychology, 7, 3-37. doi:10.1037/1089-2680.7.1.3

Ryder, A. G., Alden, L. E., \& Paulhus, D. L. (2000). Is acculturation unidimensional or bidimensional? A head-to-head comparison in the prediction of personality, self-identity, and adjustment. Journal of Personality and Social Psychology, 79, 49-65. doi:10.1037/00223514.79.1.49

Sabogal, F., Marin, G., Otero-Sabogal, R., VanOss Marin, B., \& Perez-Stable, E. J. (1987). Hispanic familism and acculturation: What changes and what doesn't?Hispanic Journal of Behavioral Sciences, 9, 397-412. doi:10.1177/07399863870094003

Schwartz, S. J., Unger, J. B., Zamboanga, B. L., \& Szapocznik, J. (2010). Rethinking the concept of acculturation: Implications for theory and research. American Psychologist, 65, 237-251. doi:10.1037/a0019330

Schwartz, S. J., Zamboanga, B. L., \& Jarvis, L. H. (2007). Ethnic identity and acculturation in Hispanic early adolescents: Mediated relationships to academic grades, prosocial behaviors, and externalizing symptoms. Cultural Diversity and Ethnic Minority Psychology, 13, 364-373. doi:10.1037/1099-9809.13.4.364

Sodowsky, G. R., Lai, E. W., \& Plake, B. S. (1991). Moderating effects of sociocultural variables on acculturation attitudes of Hispanics and Asian Americans. Journal of Counseling and Development, 70, 194204.

Sodowsky, G. R., \& Plake, B. S. (1991). Psychometric properties of the American-International Relations Scale. Educational and Psychological Measurement, 51, 207-216. doi:10.1177/0013164491511020

Stephenson, M. (2000). Development and validation of the Stephenson Multigroup Acculturation Scale (SMAS). Psychological Assessment, 12, 77-88. doi:10.1037/1040-3590.12.1.77

Journal of Counseling Psychology, Vol. 58, No. 1 (January 2011): pg. 83-96. DOI. This article is @ American Psychological Association and permission has been granted for this version to appear in e-Publications@Marquette. American Psychological Association does not grant permission for this article to be further copied/distributed or hosted elsewhere without the express permission from American Psychological Association. 
NOT THE PUBLISHED VERSION; this is the author's final, peer-reviewed manuscript. The published version may be accessed by following the link in the citation at the bottom of the page.

Suinn, R. M., Knoo, G., \& Ahuna, C. (1995). The Suinn-Lew Asian SelfIdentity Acculturation Scale: Cross-cultural information. Journal of Multicultural Counseling and Development, 23, 139-148.

Suinn, R. M., Rickard-Figueroa, K., Lew, S., \& Vigil, P. (1987). The Suinn-Lew Asian Self-Identity Acculturation Scale: An initial report. Educational and Psychological Measurement, 47, 401-407. doi: $10.1177 / 0013164487472012$

Swagler, M. A., \& Jome, L. M. (2005). The effects of personality and acculturation on the adjustment of North American sojourners in Taiwan. Journal of Counseling Psychology, 52, 527-536. doi: $10.1037 / 0022-0167.52 .4 .527$

Szapocznik, J., \& Kurtines, W. (1980). Acculturation, biculturalism, and adjustment among Cuban Americans. In A. M.Padilla (Ed.), Psychological dimensions on the acculturation process: Theory, models, and some new findings (pp. 139-159). Boulder, CO: Westview Press.

Szapocznik, J., Kurtines, W., \& Fernandez, T. (1980). Bicultural involvement and adjustment in Hispanic-American youths. International Journal of Intercultural Relations, 4, 353-365. doi:10.1016/01471767(80)90010-3

Torres, L., \& Rollock, D. (2007). Acculturation and depression among Hispanics: The moderating effect of intercultural competence. Cultural Diversity and Ethnic Minority Psychology, 13, 10-17. doi: $10.1037 / 1099-9809.13 .1 .10$

Tsai, J., Ying, Y. W., \& Lee, P. A. (2000). The meaning of "being Chinese" and "being American."Journal of Cross-Cultural Psychology, 31, 302-332. doi: $10.1177 / 0022022100031003002$

U.S. Census Bureau. (2007a). The American community-Asians: 2004. Washington, DC: Author.

U.S. Census Bureau. (2007b). The American community-Hispanics: 2004. Washington, DC: Author.

U.S. Census Bureau. (2008). Profiles of general demographic characteristics. Washington, DC: Author.

Journal of Counseling Psychology, Vol. 58, No. 1 (January 2011): pg. 83-96. DOI. This article is @ American Psychological Association and permission has been granted for this version to appear in e-Publications@Marquette. American Psychological Association does not grant permission for this article to be further copied/distributed or hosted elsewhere without the express permission from American Psychological Association. 
NOT THE PUBLISHED VERSION; this is the author's final, peer-reviewed manuscript. The published version may be accessed by following the link in the citation at the bottom of the page.

Wang, C. D. C., \& Mallinckrodt, B. (2006). Acculturation, attachment, and psychosocial adjustment of Chinese/Taiwanese international students. Journal of Counseling Psychology, 53, 422-433. doi:10.1037/00220167.53.4.422

Wolfe, M. M., Yang, P. H., Wong, E. C., \& Atkinson, D. R. (2001). Design and development of the European American Values Scale for Asian Americans. Cultural Diversity and Ethnic Minority Psychology, 7, 274283. doi:10.1037/1099-9809.7.3.274

Wong, Y. J., Tran, K. K., \& Lai, A. (2009). Associations among Asian Americans' enculturation, emotional experiences, and depressive symptoms. Journal of Multicultural Counseling and Development, 37, 105-116.

Worthington, R. L., Soth-McNett, A. M., \& Moreno, M. V. (2007). Multicultural counseling competencies research: A 20-year content analysis. Journal of Counseling Psychology, 54, 351-361. doi:10.1037/00220167.54.4.351

Yeh, C. J. (2003). Age, acculturation, cultural adjustment, and mental health symptoms of Chinese, Korean, and Japanese immigrant youths. Cultural Diversity and Ethnic Minority Psychology, 9, 34-48. doi:10.1037/1099-9809.9.1.34

Yoon, E. (2006). Acculturation, social connectedness, and subjective well-being(Unpublished doctoral dissertation). University of Minnesota, Minneapolis.

Yoon, E. (2010). Structure and measurement of ethnic identity using the EIS and the MEIM-R. Manuscript submitted for publication.

Yoon, E., Lee, D., Koo, Y., \& Yoo, S. (2010). A qualitative investigation of Korean immigrant women's lives. The Counseling Psychologist, 38, 523-553. doi:10.1177/0011000009346993

Zea, M. C., Asner-Self, K. K., Birman, D., \& Buki, L. P. (2003). The Abbreviated Multidimensional Acculturation Scale: Empirical validation with two Latino/Latina samples. Cultural Diversity and Ethnic Minority Psychology, 9, 107-126. doi:10.1037/10999809.9.2.107

Journal of Counseling Psychology, Vol. 58, No. 1 (January 2011): pg. 83-96. DOI. This article is @ American Psychological Association and permission has been granted for this version to appear in e-Publications@Marquette. American Psychological Association does not grant permission for this article to be further copied/distributed or hosted elsewhere without the express permission from American Psychological Association. 
NOT THE PUBLISHED VERSION; this is the author's final, peer-reviewed manuscript. The published version may be accessed by following the link in the citation at the bottom of the page.

\section{Appendix}

\section{Table 1}

\section{Top PsycINFo Peer Reviewed Journals Publishing Acculturation- Related Empirical Research}

\begin{tabular}{|c|c|c|c|}
\hline Rank & Joumal & $\begin{array}{c}\text { Publication year } \\
\text { of first issue }\end{array}$ & $\begin{array}{c}\text { Total number } \\
\text { of hits }\end{array}$ \\
\hline 1 & Hispanic Journal of Behavioral Sciences & 1979 & 141 \\
\hline 2 & International Journal of Intercultural Relations & 1977 & 129 \\
\hline 3 & Cultural Diversity and Ethnic Minorify Psychology & 1995 & 96 \\
\hline 4 & Joarnal of Cross-Cularal Psychology & 1970 & 92 \\
\hline 5 & Journal of Counseling Psychology & 1954 & 51 \\
\hline 5 & Social Science \& Medicine. & 1967 & 51 \\
\hline 7 & International Journal of Psychology & 1966 & 42 \\
\hline 8 & Journal of Commustity Psychology & 1973 & 36 \\
\hline 9 & American Journal of Public Healthi & 1911 & 35 \\
\hline 10 & Journal of Multicultural Counseling and Development: & 1973 & 27 \\
\hline
\end{tabular}

Note. The number of hits includes both quantitative and qualitative studies as a result of a PsycINFO keyword search of acculturation, enculturation, cultural values, and acculturation gap.

Journal of Counseling Psychology, Vol. 58, No. 1 (January 2011): pg. 83-96. DOI. This article is @ American Psychological Association and permission has been granted for this version to appear in e-Publications@Marquette. American Psychological Association does not grant permission for this article to be further copied/distributed or hosted elsewhere without the express permission from American Psychological Association. 
Table 2

Conceptualization and Use of Acculturation/Enculturation Variables

\begin{tabular}{|c|c|c|c|}
\hline Variable & $N$ & Frequency (no.) & $\%$ \\
\hline Linearity & 162 & & \\
\hline Unilinear & & 72 & 44.4 \\
\hline Bilinear & & 48 & 29.6 \\
\hline Acculturation & & 7 & 4.3 \\
\hline Enculturation only & & 30 & 18.5 \\
\hline Other (e.g., trilinear) & & 5 & 3.1 \\
\hline Dimensionality & 162 & & \\
\hline Total score & & 101 & 62.3 \\
\hline Dimension specific score & & 46 & 28.4 \\
\hline Both total score and dimension score & & 10 & 6.2 \\
\hline Other (e.g., one item measure) & & 5 & 3.1 \\
\hline Context & 138 & & \\
\hline Included & & 4 & 2.9 \\
\hline Not included & & 134 & 97.1 \\
\hline Continuous vs. categorical & 162 & & \\
\hline Continuous variable & & 131 & 80.9 \\
\hline Categorical variable & & 28 & 17.3 \\
\hline Both continuous and categorical & & 3 & 1.9 \\
\hline Role & 170 & & \\
\hline Predictor & & 118 & 69.4 \\
\hline Outcome & & 16 & 9.4 \\
\hline Mediator & & 3 & 1.8 \\
\hline Moderator & & 14 & 8.2 \\
\hline Covariate & & 4 & 2.4 \\
\hline Other (e.g., variable for factor analysis) & & 15 & 8.8 \\
\hline
\end{tabular}

Journal of Counseling Psychology, Vol. 58, No. 1 (January 2011): pg. 83-96. DOI. This article is @ American Psychological Association and permission has been granted for this version to appear in e-Publications@Marquette. American Psychological Association does not grant permission for this article to be further copied/distributed or hosted elsewhere without the express permission from American Psychological Association. 
NOT THE PUBLISHED VERSION; this is the author's final, peer-reviewed manuscript. The published version may be accessed by following the link in the citation at the bottom of the page.

\section{Table 3}

\section{Research Design}

\begin{tabular}{|c|c|c|c|}
\hline Variable & $N$ & Frequency (no.) & $\%$ \\
\hline Sample characteristics: Race/ethnicity & 148 & & \\
\hline European American & & 7 & 4.7 \\
\hline African American & & 5 & 3.4 \\
\hline Latinola & & 45 & 30.4 \\
\hline Asian American & & 76 & 51.4 \\
\hline Native American & & 3 & 2.0 \\
\hline No distinction & & 12 & 8.1 \\
\hline Sample characteristics: Sampling source & 138 & & \\
\hline Kindergarten -12 schools & & 20 & 14.5 \\
\hline College eampus & & 78 & 565 \\
\hline Community & & 24 & 17.4 \\
\hline Other (e.g., prison, mental health clinic) & & 16 & 11.6 \\
\hline Study type & 138 & & \\
\hline Survey & & 122 & 88.4 \\
\hline Experiment-Laboratory & & 8 & 5.8 \\
\hline Experiment-Field & & 7 & 5.1 \\
\hline Clinician's rating & & 1 & 0.7 \\
\hline Data collection: Language & 138 & & \\
\hline English only & & 119 & 86.2 \\
\hline Other language(s) only & & 6 & 4.3 \\
\hline English + other language(s) & & 13 & 9.4 \\
\hline Data analysis method & 197 & & \\
\hline Comelation and regression (excluding moderation, mediation tests) & & 95 & 482 \\
\hline Mean comparison & & 48 & 24.4 \\
\hline Moderation test (using analysis of variance or multiple regression) & & 16 & 8.1 \\
\hline Mediation test (using multiple regression) & & 4 & 2.0 \\
\hline Path analysis and structural equation modeling (excluding & & & \\
\hline confimatory factor analysis) & & 13 & 6.6 \\
\hline Factor analysis (exploratory and confirmatory) & & 10 & 5.1 \\
\hline Other (e.g, cluster analysis, chi-square) & & 11 & 5.6 \\
\hline
\end{tabular}

Journal of Counseling Psychology, Vol. 58, No. 1 (January 2011): pg. 83-96. DOI. This article is @ American Psychological Association and permission has been granted for this version to appear in e-Publications@Marquette. American Psychological Association does not grant permission for this article to be further copied/distributed or hosted elsewhere without the express permission from American Psychological Association. 
NOT THE PUBLISHED VERSION; this is the author's final, peer-reviewed manuscript. The published version may be accessed by following the link in the citation at the bottom of the page.

\section{Table 4}

\section{Frequently Used Acculturation/Enculturation Measures}

\begin{tabular}{|c|c|c|c|c|c|c|c|}
\hline \multirow[b]{2}{*}{ Rank: } & \multirow[b]{2}{*}{ Mersente } & \multirow[b]{2}{*}{ Dimensions } & \multicolumn{5}{|c|}{ Frequency (no.) } \\
\hline & & & Tceal & $1988-1995$ & $1996-2000$ & $2001-2005$ & $2006-2009$ \\
\hline 1 & $\begin{array}{l}\text { Suin n-Lew Asian Self Ideatity } \\
\text { Acculturation Sale (Stuinn at } \\
\text { al., 1987) }\end{array}$ & 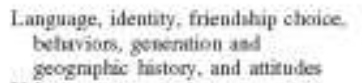 & 29 & 10 & 5 & 14 & 0 \\
\hline 2 & $\begin{array}{l}\text { Asian Values Scale (Kim et al. } \\
\text { 1999) }\end{array}$ & Value & 20 & 0 & 1 & 11 & 8 \\
\hline 3 & $\begin{array}{l}\text { Aoculturation Rating Scale for } \\
\text { Moxican Amerisass (Cuellar at } \\
\text { al., 1980) }\end{array}$ & $\begin{array}{l}\text { Language, eshuic internstion, ethnic } \\
\text { idemity, caltural loctiage, asd } \\
\text { generation }\end{array}$ & 17 & 9 & 5 & 3 & 0 \\
\hline 4 & $\begin{array}{l}\text { Acenituration Ratiog Scale for } \\
\text { Moxican Americass-II } \\
\text { (Cuellar et al, 1995) }\end{array}$ & $\begin{array}{l}\text { Language, cultural activity, ethaic } \\
\text { identity, and sucial interaction }\end{array}$ & 12 & 0 & 3 & 2 & 7 \\
\hline 5 & $\begin{array}{l}\text { Proxy messures (eg-age of } \\
\text { immignrion, gonenational } \\
\text { staus) }\end{array}$ & & 7 & 2 & 1 & 3 & 1 \\
\hline 6 & $\begin{array}{l}\text { Abbreviated Multidimessional } \\
\text { Acculturatioa Scale (Zea et al. } \\
\text { 2005) }\end{array}$ & $\begin{array}{l}\text { Identity, language competence. and } \\
\text { cukunal competence }\end{array}$ & 4 & 0 & (0) & 2 & 2 \\
\hline 6 & $\begin{array}{l}\text { Arasican-International Relations } \\
\text { Scake (Sodewaky \& Plake, } \\
\text { 1991) }\end{array}$ & $\begin{array}{l}\text { Social custoeas, language uage, and } \\
\text { ferceived prejudice }\end{array}$ & 4 & 1 & 1 & 1 & 1 \\
\hline 6 & $\begin{array}{l}\text { Asian Amencan } \\
\text { Multidimenisional } \\
\text { Acculturation Ssale (Gim } \\
\text { Clung et aL, 2004) }\end{array}$ & $\begin{array}{l}\text { Cultunal behavior, cultural identiry, } \\
\text { and culnaral ksowledge }\end{array}$ & 4 & 0 & 0 & 3 & 1 \\
\hline 6 & $\begin{array}{l}\text { European Ametican Values Scale } \\
\text { for Asian Americans-Revised } \\
\text { (S. Hoog of al., 2005) }\end{array}$ & 98 & 4 & 0 & e & 2 & 2 \\
\hline 6 & $\begin{array}{l}\text { General Fhnicixy Questionnaive } \\
\text { (Tsai et al. } 2000 \text { ) }\end{array}$ & $\begin{array}{l}\text { Language, social affiliation, activitios, } \\
\text { pribe, exposure, modia, and food }\end{array}$ & 4 & 0 & 0 & 1 & 3 \\
\hline 11 & $\begin{array}{l}\text { Asian Arrorican Values Srale- } \\
\text { Multidimensional (Kim et al., } \\
2005)\end{array}$ & Values & 3 & 0 & 0 & 0 & 3 \\
\hline 11 & $\begin{array}{l}\text { Bidimensional Acculturation } \\
\text { Scak (Maria \& Gamba, 1996) }\end{array}$ & $\begin{array}{l}\text { Language nse, lisgristic proficiency. } \\
\text { and elestronic media }\end{array}$ & 3 & 0 & 0 & 0 & 3 \\
\hline 11 & $\begin{array}{l}\text { Cultaral Identification Stale } \\
\text { (Oetting \& Beanveis, 1990- } \\
\text { 1991) }\end{array}$ & Celtenal way of bife & 3 & 0 & 0 & 5 & 0 \\
\hline 11 & $\begin{array}{l}\text { Cultural Life Style Inventory } \\
\text { (Mesdaza, 1989) }\end{array}$ & $\begin{array}{l}\text { Language, social affiliation, cultural } \\
\text { famaliarity, isentification, stod pride }\end{array}$ & 3 & 0 & 0 & 1 & 2 \\
\hline 11 & $\begin{array}{l}\text { European Amstican Values Scale } \\
\text { for Asian Americans (Wolfe et } \\
\text { al. } 2006 \text { ) }\end{array}$ & Values & 3 & 0 & 0 & 2 & 1 \\
\hline 11 & $\begin{array}{l}\text { Majonity-Minonity Relations } \\
\text { Sunvey (Sodowiky et al. } \\
\text { 1991) }\end{array}$ & $\begin{array}{l}\text { Social custonts, language ntage, and } \\
\text { penceived prejodice }\end{array}$ & 3 & 1 & 0 & 2 & 0 \\
\hline 11 & $\begin{array}{l}\text { Shod Accelterntion Scale (Marin } \\
\text { et al. 1987) }\end{array}$ & $\begin{array}{l}\text { Language, ectuic social welations, and } \\
\text { modia }\end{array}$ & 3 & 0 & 3 & 0 & 0 \\
\hline 11 & $\begin{array}{l}\text { Stepheuson Multigrodp } \\
\text { Accuituratina Scule } \\
\text { (Siepbenson, 2000) }\end{array}$ & Language nse, food, and eatestainment & 3 & 0 & a & 6 & 3 \\
\hline
\end{tabular}

Journal of Counseling Psychology, Vol. 58, No. 1 (January 2011): pg. 83-96. DOI. This article is @ American Psychological Association and permission has been granted for this version to appear in e-Publications@Marquette. American Psychological Association does not grant permission for this article to be further copied/distributed or hosted elsewhere without the express permission from American Psychological Association. 
NOT THE PUBLISHED VERSION; this is the author's final, peer-reviewed manuscript. The published version may be accessed by following the link in the citation at the bottom of the page.

\section{Table 5}

\section{Description of Studies for Meta-Analyses}

\begin{tabular}{|c|c|c|c|c|c|c|}
\hline \multirow[b]{2}{*}{ Study } & \multirow[b]{2}{*}{ Sample charasteristics } & \multirow{2}{*}{$\begin{array}{l}\text { Sample } \\
\text { sibe ( }(x)\end{array}$} & \multicolumn{2}{|c|}{$\begin{array}{l}\text { Psycholngical } \\
\text { distress aad } \\
\text { depresition }\end{array}$} & \multicolumn{2}{|c|}{ Self-esteem } \\
\hline & & & $\mathrm{AOC}$ & ENC & $A C C$ & $\mathrm{ENC}$ \\
\hline Birman \& Trylor-Riteker $(200 \pi)$ & $\begin{array}{l}\text { Adolescent immigrants to the United Sates } \\
\text { from the former Soviet Union }\end{array}$ & 226 & -19 & $\sqrt{67}$ & & \\
\hline Cautillo et al. (2004) & Mexisun Anerican female college studenes & 243 & 103. & & & \\
\hline Céspedes \& Huey (ZOOS) & Larinofa youtha in the United Sates & 130 & 08 & .05 & & \\
\hline Gonzalez ef al. (1997) & Mexican Araetican adults. & 23 & -.13 & & & \\
\hline Hwang \& Tinz (2008) & Asian Atwerican collegre stujents & 185 & -16 & 10 & & \\
\hline Mondi \& Riseo (2006) & Latinoh Americans in college and communuty & 128 & -.04 & -.03 & 03 & 23 \\
\hline Obasi \& Leong (2009) & African Americass in college and community & 130 & .28 & -.07 & & \\
\hline Olvera er al. (2007) & Lafinods Amerisan adult: & 96 & 18 & .06 & & \\
\hline Rahinan \& Rolloek (2004)" & $\begin{array}{l}\text { South Aaras inernational sudents in the } \\
\text { Unibed Sates: }\end{array}$ & 105 & & -01 & & \\
\hline Rodrigues et al $(2003)^{\circ}$ & Latinofa colloge students in the United States & 338 & -.01 & .03 & & \\
\hline Tumes \& Rollock (2007) & Hispanic aduls in the United States & 96 & -.27 & & & \\
\hline Waug \& Malliackrodt (2006) & $\begin{array}{l}\text { Chinese/Taiwanee iateanaional stodeats in } \\
\text { the United Srates }\end{array}$ & 104 & -45 & -.16 & & \\
\hline Wobzet al $(2000)$ & Asian American colloge students & 218 & & 17 & & \\
\hline Yeh (2003) & $\begin{array}{l}\text { Chibsec, Japneses, and Keocal inmigrant } \\
\text { youths in the United States: }\end{array}$ & 319 & -05 & & & \\
\hline Cavaros Rehg \& Delecia Wack (2005)' & Latinoh youths in the United sates & 144 & & & & -.08 \\
\hline Giang \& Wirtig (2000) & $\begin{array}{l}\text { Diverse iacial groves of youth in the United } \\
\text { Sales }\end{array}$ & $35 i$ & & & 30 & .18 \\
\hline Schwarte of al (2007) & Higyanic youths in the United Saies & 347 & & & -04 & 17 \\
\hline Trai et al. $(2000)^{\circ}$ & Chinese Amerixall college utndents. & 353 & & & 09 & .44 \\
\hline
\end{tabular}

Note. $A C C=$ acculturation; $E N C=$ enculturation. a Effect sizes are based on standardized regression weights.

Journal of Counseling Psychology, Vol. 58, No. 1 (January 2011): pg. 83-96. DOI. This article is @ American Psychological Association and permission has been granted for this version to appear in e-Publications@Marquette. American Psychological Association does not grant permission for this article to be further copied/distributed or hosted elsewhere without the express permission from American Psychological Association. 
NOT THE PUBLISHED VERSION; this is the author's final, peer-reviewed manuscript. The published version may be accessed by following the link in the citation at the bottom of the page.

\section{Figure 1}

Changes in total publications (1988-2009)

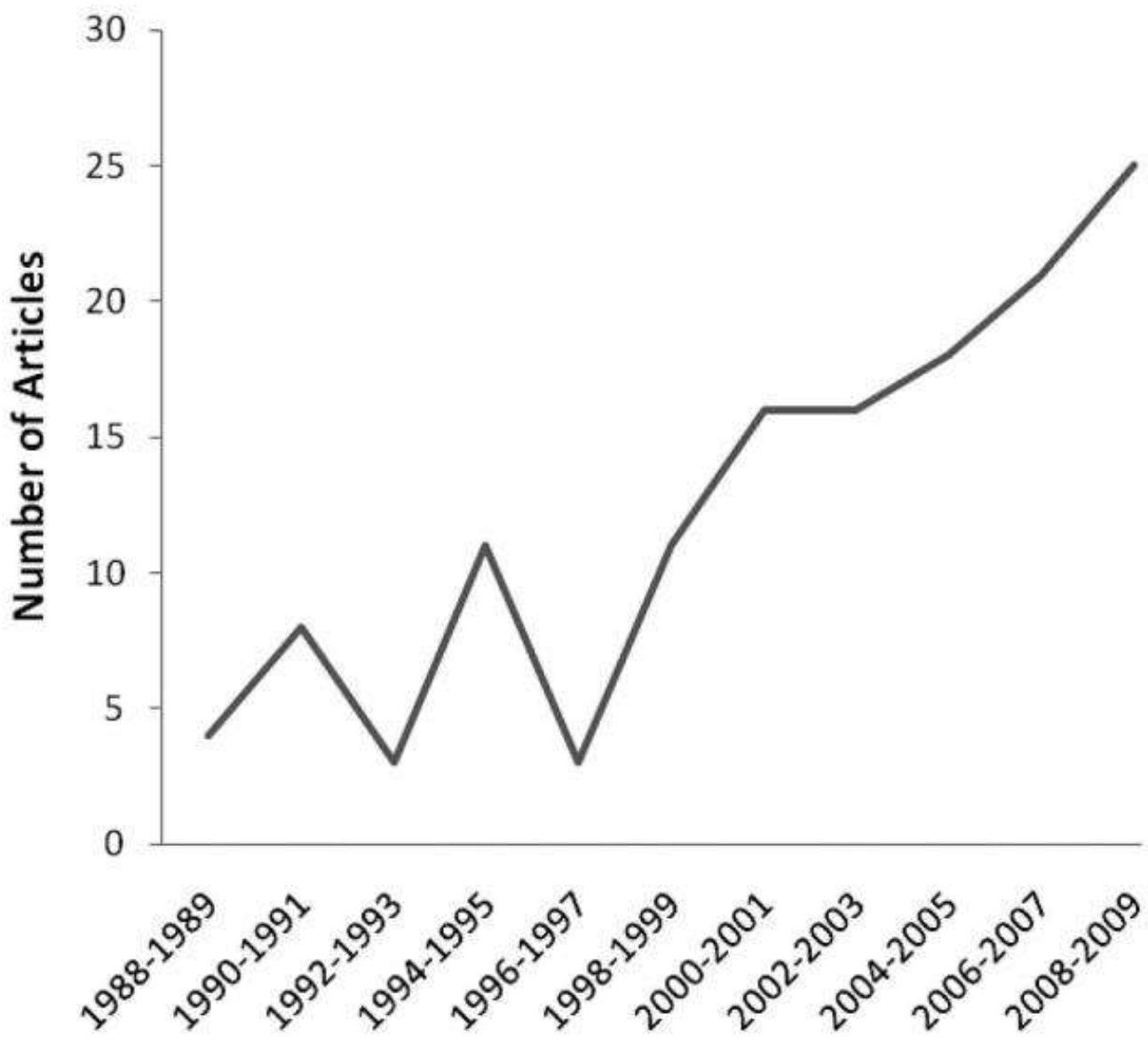

\section{Publication Year}

Journal of Counseling Psychology, Vol. 58, No. 1 (January 2011): pg. 83-96. DOI. This article is @ American Psychological Association and permission has been granted for this version to appear in e-Publications@Marquette. American Psychological Association does not grant permission for this article to be further copied/distributed or hosted elsewhere without the express permission from American Psychological Association. 